JPPKMI 1 (1) (2020)
JURNAL PENELITIAN DAN PENGEMBANGAN
KESEHATAN MASYARAKAT INDONESIA
Jttps://journal.unnes.ac.id/sju/index.php/jppkmi

\title{
Hipertensi pada Remaja di Kabupaten Semarang
}

\author{
Yuliaji Siswanto ${ }^{1} \bowtie$, Sigit Ambar Widyawati ${ }^{1}$, Alya Asyura Wijaya ${ }^{1}$, Budi Dewi Salfana ${ }^{1}$, \\ Karlina $^{1}$
}

${ }^{1}$ Program Studi Kesehatan Masyarakat, Fakultas Ilmu Kesehatan, Universitas Ngudi Waluyo

\section{Info Artikel Abstrak}

Sejarah Artikel:

Diterima Mei 2020

Disetujui Juni 2020

Dipublikasikan Juli 2020

Keywords:

hypertension, adolescence,

knowledge

$U R L:$

https://iournal.unnes.ac.i d/siu/index.php/ippkmi /article/view/41433/173 $\underline{36}$

\begin{abstract}
Pendahuluan: Hipertensi umumnya terjadi pada usia lanjut, tetapi beberapa penelitian menunjukkan bahwa hipertensi dapat muncul sejak remaja dan prevalensinya mengalami peningkatan selama beberapa dekade terakhir. Namun banyak yang belum menyadari sehingga menjadi penyebab munculnya hipertensi pada usia dewasa dan lansia. Penelitian ini bertujuan untuk mengetahui prevalensi hipertensi pada remaja di Kabupaten Semarang. Metode: Penelitian dilakukan secara observasional dengan pendekatan cross sectional. Sampel penelitian sebanyak 147 responden yang diambil dengan two stage cluster sampling. Pengumpulan data dengan kuesioner, pengukuran berat badan, tinggi badan, dan tekanan darah. Data dianalisis secara univariat dengan menggunakan tabel distribusi frekuensi. Hasil: Hasil penelitian mendapatkan responden laki - laki sebanyak 73 orang $(49,7 \%)$ dan perempuan sebanyak 74 orang $(50,3 \%)$. Sebagian besar $(77,6 \%)$ responden mempunyai tingkat pengetahuan sedang. Hasil pengukuran tekanan darah menunjukkan sebanyak 9 orang $(6,1 \%)$ kategori hipertensi stage 2 , sebanyak 18 orang $(12,2 \%)$ termasuk kategori hipertensi stage 1 , sebanyak 22 orang $(15,0 \%)$ termasuk kategori pre-hipertensi dan sebanyak 98 orang $(66,7 \%)$ mempunyai tekanan darah normal. Penutup: Hasil penelitian menunjukkan bahwa sepertiga responden sudah mengalami hipertensi.
\end{abstract}

\begin{abstract}
Introduction: Hypertension generally occurs in the elderly, but several studies have shown that hypertension can occur since adolescence and its prevalence has increased over the last few decades. However, many are not aware that it is the causes of hypertension in adults and the elderly. This study aims to determine the prevalence of hypertension among adolescents in Semarang Regency. Methods: The study was conducted in an observational with approach cross sectional. The research sample as many as 147 respondents who were taken by two stage cluster sampling. Data was collected using questionnaire, measurement of body weight, height and blood pressure. Data was analyzed univariately using frequency distribution tables. Results: The results showed that 73 respondents were male (49.7\%) and 74 female respondents (50.3\%). Most (77.6\%) of respondents have a moderate level of knowledge. The results of blood pressure measurement showed 9 people (6.1\%) had stage 2 hypertension, 18 people (12.2\%) had stage 1 hypertension, 22 people (15.0\%) had prehypertension and as many as 98 people (66.7 \%) have normal blood pressure. Closing: Research shows that one third of respondents already have hypertension.
\end{abstract}

$\bowtie$ Alamat korespondensi:

J1. Diponegoro No.186, Ngablak, Gedanganak, Kec.

Ungaran Timur, Semarang, Jawa Tengah 50512

E-mail: vuliaii2000@unw.ac.id 


\section{PENDAHULUAN}

Hipertensi merupakan salah satu masalah kesehatan yang cukup berbahaya di dunia, karena hipertensi merupakan faktor risiko utama yang mengarah kepada penyakit kardiovaskuler seperti serangan jantung, gagal jantung, stroke dan penyakit ginjal yang mana pada tahun 2016 penyakit jantung iskemik dan stroke menjadi dua penyebab kematian utama di dunia (WHO, 2018).

Kejadian hipertensi di seluruh dunia mencapai lebih dari 1,3 milyar orang, yang mana angka tersebut menggambarkan $31 \%$ jumlah penduduk dewasa di dunia yang mengalami peningkatan sebesar $5,1 \%$ lebih besar dibanding prevalensi global pada tahun 2000-2010 (Bloch, 2016). Prevalensi kejadian hipertensi di Indonesia yang didapatkan dari hasil pengukuran tekanan darah pada penduduk berusia $\geq 18$ tahun mengalami peningkatan dari $25,8 \%$ pada tahun 2013 menjadi $34,11 \%$. Jawa Tengah menempati peringkat ke-empat terjadinya hipertensi di Indonesia yaitu sebesar 37,57\% (Kemenkes RI, 2018). Data Profil Kesehatan Jawa Tengah, penyakit hipertensi menempati proporsi terbesar dari penyakit tidak menular yang dilaporkan, yaitu sebesar 57,87\% (Dinkes Provinsi Jateng, 2015). Berdasarkan Profil Kesehatan Kabupaten Semarang didapatkan peningkatan kejadian hipertensi dari tahun 2013 hingga tahun 2015, yaitu sebanyak 35.294 kasus menjadi 40.869 kasus dan 41.134 kasus.

Hipertensi umumnya terjadi pada usia lanjut, tetapi beberapa penelitian menunjukkan bahwa hipertensi dapat muncul sejak remaja dan prevalensinya mengalami peningkatan selama beberapa dekade terakhir, namun banyak yang belum menyadari sehingga menjadi penyebab munculnya hipertensi pada usia dewasa dan lansia.

Hipertensi merupakan kondisi yang penting pada anak-anak, dengan perkiraan prevalensi populasi $1-2 \%$ di negara maju. Survei nutrisi di AS menunjukkan adanya peningkatan yang signifikan dalam tekanan darah sistolik dan tekanan darah diastolik. Penyebab peningkatan tekanan darah dikaitkan dengan obesitas, perubahan pola makan, penurunan aktivitas fisik dan meningkatnya stres (Sangamesh, 2016). Prevalensi hipertensi pada remaja sebesar $9 \%$ pada tahun 2007 , kemudian meningkat menjadi $10,7 \%$ pada tahun 2013 (Kemenkes RI, 2013). Remaja dan dewasa muda yang berada pada kisaran usia 15-25 tahun memiliki angka prevalensi hipertensi 1 dari 10 orang.

Pada penelitian yang dilakukan oleh Kini (2016), prevalensi prehipertensi dan hipertensi pada dewasa muda (usia 20-30 tahun) adalah sebesar 45,2\%. Penelitian yang dilakukan Fitrianingsih (2015) mendapatkan kejadian hipertensi pada remaja di SMAN 1 Ungaran sebesar $57,6 \%$.

Mekanisme terjadinya hipertensi pada remaja dipengaruhi oleh beberapa faktor yang berkaitan dengan gaya hidup. Faktor tersebut diantaranya adalah berat badan lebih atau obesitas, riwayat hipertensi dalam keluarga atau faktor genetik, ras atau etnik, jenis kelamin, berat lahir rendah, konsumsi garam yang tinggi, merokok, aktivitas fisik atau olahraga dan pengetahuan rendah. Faktor risiko gaya hidup tidak sehat pada remaja disebabkan oleh banyak faktor, salah satu diantaranya adalah pengetahuan. Pengetahuan atau kognitif merupakan domain yang sangat berpengaruh terhadap tindakan atau perilaku seseorang (Notoatmodjo, 2012).

Rendahnya pengetahuan tenaga kesehatan, pasien, dan masyarakat tentang hipertensi merupakan penyebab utama tidak terkontrolnya tekanan darah, terutama pada pasien hipertensi di Asia (Park, J.B., 2015).Halhal yang dapat dilakukan sebagai upaya perbaikan kesehatan bukan sekadar memperbaiki kerusakan atau kelainan fisik, tetapi melibatkan kompleksitas kebutuhan, motivasi, dan prioritas individu yang dapat dilakukan melalui komunikasi intrapersonal yang melibatkan jiwa, kemauan, kesadaran, dan pikiran (Arianto, 2013).

Penelitian ini bertujuan untuk mengatahui prevalensi hipertensi pada remaja di Kabupaten Semarang. 


\section{METODE}

Penelitian dilakukan secara observasional dengan pendekatan cross sectional yang bertujuan untuk mengetahui prevalensi hipertensi pada remaja di Kabupaten Semarang, dengan cara pendekatan observasi atau pengumpulan data sekaligus pada suatu saat (point time approach). Penelitian ini dilakukan di wilayah Kabupaten Semarang yang terdiri dari 19 kecamatan dan terdapat 60 SMA/SMK/MA. Populasi yang diambil adalah seluruh remaja yang tercatat di SMA/SMK/MA yang ada di Kabupaten Semarang pada tahun ajaran 2018/2019, yaitu sebanyak 30.230 siswa. Sampel penelitian ini merupakan bagian dari populasi yang ditentukan dengan rumus sampel survei pada populasi finit sebanyak 147 siswa. Pengambilan sampel dilakukan dengan two stage cluster sampling. Pada tahap pertama dilakukan pemilihan kelompok sebagai sampel, yaitu memilih kecamatan sebagai kelompok/cluster. Pemilihan kelompok di dapat Kecamatan Bergas, Kecamatan Sumowono dan Kecamatan Ungaran. Selanjutnya diambil satu SMA yang berada kelompok tersebut, dan didapatkan SMA Negeri 1 Bergas, SMK Sumowono dan SMA Negeri 2 Ungaran. Kemudian tahap kedua memilih siswa dari ketiga SMA/SMK/MA, didapatkan 49 remaja dari SMA Negeri 1 Bergas, 49 remaja dari SMK Sumowono dan 49 remaja dari SMA Negeri 2 Ungaran.

Variabel-variabel yang diukur dalam penelitian ini meliputi: prevalensi hipertensi, jenis kelamin, dan tingkat pengetahuan mengenai hipertensi pada remaja. Data dikumpulkan dengan menggunakan kuesioner dan pengukuran fisik yaitu berat badan, tinggi badan, dan tekanan darah. Analisis data dilakukan secara univariat dengan menggunakan tabel distribusi frekuensi.

\section{HASIL DAN PEMBAHASAN}

Masa remaja yang merupakan peralihan anak menjadi dewasa menyebabkan remaja berbeda dengan anak dan dewasa baik dalam gaya hidup dan kebiasaan maupun perubahan metabolik dalam tubuh. Hal itu menyebabkan pola penyakit pada remaja berbeda dengan anak yang lebih muda. Dengan perubahan gaya hidup menyebabkan remaja rentan terhadap timbulnya berbagai penyakit dan salah satu di antaranya adalah hipertensi.

Prevalensi di negara maju sebesar 35\% dan di negara berkembang sebesar $40 \%$ dari populasi dewasa. Pada tahun 2025 diperkirakan kasus hipertensi terutama di negara berkembang akan mengalami peningkatan $80 \%$ dari 639 juta kasus di tahun 2000, yaitu menjadi 1,15 milyar kasus. Prediksi ini didasarkan pada angka penderita hipertensi dan bertambahnya penduduk saat ini (Sukarmin, 2013).

Hasil penelitian mendapatkan sebaran responden berdasarkan jenis kelamin hampir sama antara laki-laki $(49,7 \%)$ dan perempuan (50,3\%). Tingkat pengetahuan responden dibagi menjadi tiga kategori, yaitu kurang sebanyak 28 orang $(19,0 \%)$, cukup sebanyak 114 orang $(77,6 \%)$, dan baik sebanyak 5 orang $(3,4 \%)$. Hasil penelitian ini menunjukkan bahwa pengetahuan responden tentang hipertensi masih belum baik. Hasil penelitian yang dilakukan oleh Grad (2015) di Polandia mendapatkan hampir setengah dari remaja $(49,2 \%)$ memiliki tingkat pengetahuan yang rendah tentang hipertensi, hampir 38\% memiliki pengetahuan sedang, dan hanya $13 \%$ yang memiliki pengetahuan tersebut pada tingkat yang baik.

Karakteristik remaja berdasarakan jenis kelamin, pengetahuan dan kategori hepertensi dapat dilihat pada tabel 1 .

Tabel 1. Karakteristik Remaja

\begin{tabular}{lll}
\hline Karakteristik & $\mathrm{f}$ & $\%$ \\
\hline Jenis kelamin & & \\
Laki-laki & 73 & 49,7 \\
Perempuan & 74 & 50,3 \\
Pengetahuan & & \\
Kurang & 28 & 19,0 \\
Cukup & 114 & 77,6 \\
Baik & 5 & 3,4 \\
Kategori hipertensi & & \\
Hipertensi tingkat 1 & 9 & 6,1 \\
Hipertensi tingkat 2 & 18 & 12,2 \\
Pre-hipertensi & 22 & 15,0 \\
Normal & 98 & 66,7 \\
\hline
\end{tabular}


Tabel 1 menunjukkan kejadian hipertensi pada responden dengan sebaran hipertensi stage 2 sebanyak 9 orang $(6,1 \%)$, hipertensi stage 1 sebanyak 18 orang $(12,2 \%)$, dan pre-hipertensi sebanyak 22 orang $(15,0 \%)$. Hasil penelitian yang ditemukan dalam penelitian ini lebih besar jika dibandingkan dengan beberapa hasil penelitian, diantaranya yang dilakukan pada siswa dan pelajar di Surabaya yaitu 6,4\% (Santoso, 2013), yang dilakukan pada siswa SMA di Kota Semarang yaitu 12,0\% (Kurnianingtyas, 2017), dan Pangkalpinang yaitu sebesar 22,5\% (Yusrizal, 2016). Masalah hipertensi yang ditemukan dalam penelitian ini lebih rendah dibandingkan dengan penelitian yang dilakukan di SMA Negeri 1 Ungaran tahun 2015, yang menemukan dari 92 resonden terdapat $57,6 \%$ yang mengalami hipertensi (Fitrianingsih, 2016). Penelitian yang dilakukan di Jakarta juga menemukan $42,4 \%$ remaja di SMA Sejahtera 1 Depok mengalami hipertensi (persentil $\geq 95$ ) (Angesti, 2018). Perbedaan angka kejadian hipertensi tersebut, kemungkinan disebabkan karena perbedaan dalam penggunaan alat pengukur tekanan darah, jenis tangan, dan kriteria yang digunakan.

Prevalensi hipertensi berdasarkan karakteristik remaja dapat dilihat pada tabel 2 . Remaja dengan hipertensi yang memiliki pengetahuan baik hanya (20\%) sedangakn yang pengetahuannya cukup $(35,1 \%)$ dan pengetahuan kurang $(28,6 \%)$. Pemahaman seseorang diperoleh melalui pengetahuan yang merupakan hasil dari tahu dan ini terjadi setelah orang melakukan pengindraan terhadap suatu objek tertentu. Pengindraan terjadi melalui

Tabel 2. Prevalensi Hipertensi Berdasarkan Karakteristik Remaja

\begin{tabular}{lllll}
\hline \multirow{2}{*}{ Karakteristik } & \multicolumn{2}{c}{ Hipertensi } & \multicolumn{2}{c}{ Tidak Hipertensi } \\
\cline { 2 - 5 } & f & $\%$ & $\mathrm{f}$ & $\%$ \\
\hline Jenis Kelamin & & & \\
Laki-Laki & 22 & $30,1 \%$ & 51 & $69,9 \%$ \\
Perempuan & 27 & $36,5 \%$ & 47 & $63,5 \%$ \\
Tingkat Pengetahuan & & \\
Kurang & 8 & $28,6 \%$ & 20 & $71,4 \%$ \\
Cukup & 40 & $35,1 \%$ & 74 & $64,9 \%$ \\
Baik & 1 & $20,0 \%$ & 4 & $80,0 \%$ \\
\hline
\end{tabular}

pancaindra manusia, yakni indra penglihatan, pendengaran, penciuman, rasa dan raba. Sebagian besar pengetahuan manusia diperoleh melalui mata dan telinga. Pengetahuan akan mendasari kepercayaan tentang suatu objek dan akan membentuk suatu kebiasaan, hal inilah yang kemudian akan memunculkan kemauan yang dimunculkan dalam sikap dan perilaku (Notoatmodjo, 2012). Grad (2015) mengatakan bahwa remaja yang tekanan darahnya pernah diperiksa yang menunjukkan pengetahuan yang baik tentang hipertensi, dengan sumber informasi paling banyak adalah dari sekolah.

Kejadian hipertensi biasanya terjadi pada kelompok usia lanjut, tetapi beberapa penelitian menunjukkan bahwa hipertensi dapat muncul sejak remaja dan prevalensinya mengalami peningkatan pada beberapa tahun terakhir (Kurnianingtyas, 2017). Kondisi ini perlu diwaspadai mengingat hipertensi pada usia remaja akan menimbulkan efek gangguan pada berbagai organ dan merupakan faktor risiko berbagai penyakit degeneratif usia lanjut, termasuk penyakit kardiovaskuler. Butch (2011) juga menyatakan bahwa remaja dengan tekanan darah tinggi dapat meningkatkan risiko hipertensi pada usia dewasa dan menderita komplikasi penyakit yang ditimbulkan oleh hipertensi.

Banyak faktor penyebab hipertensi pada remaja, yang bisa dibedakan menjadi faktor risiko yang dapat diubah dan yang tidak dapat diubah. Upaya pencegahan dan penanggulangan hipertensi didasarkan pada faktor risiko yang dapat diubah diantaranya perubahan pola makan dan gaya hidup. Upaya pencegahan yang dapat dilakukan meliputi: perubahan pola makan, pembatasan penggunaan garam hingga 4-6 gr per hari, makanan yang mengandung soda kue, bumbu penyedap dan pengawet makanan, mengurangi makanan yang mengandung kolesterol tinggi (jeroan, kuning telur, cumi-cumi, kerang, kepiting, coklat, mentega, dan margarin), menghentikan kebiasaan merokok, minum alcohol, olah raga teratur dan menghindari stress. Pendapat lain menyatakan bahwa faktor risiko yang dapat diubah meliputi obesitas, 
asupan natrium berlebih, kebiasaan merokok, aktivitas fisik, dan kualitas tidur. Sedangkan faktor risiko yang tidak dapat diubah meliputi riwayat hipertensi keluarga, berat lahir rendah, dan jenis kelamin (Dharnidharka, 2015 \& Nuraini, 2015).

Kejadian hipertensi pada remaja banyak yang diawali dengan kegemukan atau obesitas yang berkaitan dengan gaya hidup. Hasil penelitian ini menunjukkan bahwa kejadian hipertensi lebih banyak dialami oleh responden perempuan $(36,5 \%)$ dibandingkan dengan responden laki-laki $(30,1 \%)$. Hal ini bisa dikarenakan karena gaya hidup terutama pola makan remaja perempuan yang lebih suka mengkonsumsi makanan berlemak atau tinggi natrium.Pola asupan garam dalam diet: badan kesehatan dunia yaitu World Health Organization (WHO) merekomendasikan pola konsumsi garam yang dapat mengurangi risiko terjadinya hipertensi. Kadar sodium yang direkomendasikan adalah tidak lebih dari 100 mmol (sekitar 2,4 gram sodium atau 6 gram garam) perhari. Konsumsi natrium yang berlebih menyebabkan konsentrasi natrium di dalam cairan ekstraseluler meningkat. Untuk menormalkannya cairan intraseluler ditarik ke luar, sehingga volume cairan ekstraseluler meningkat. Meningkatnya volume cairan ekstraseluler tersebut menyebabkan meningkatnya volume darah, sehingga berdampak kepada timbulnya hipertensi (Shapo, 2003).

Hasil penelitian ini berbeda dengan beberapa penelitian yang dilakukan sebelumnya, seperti yang dilakukan Arum (2019) yang mendapatkan bahwa kejadian hipertensi lebih banyak dialami oleh remaja laki-laki $(43,7 \%)$ dibandingkan perempuan $(31,0 \%)$. Sementara penelitian Yusrizal, dkk (2016) juga menunjukkan ada perbedaan yang signifikan kejadian hipertensi pada remaja laki-laki dan perempuan. Hal tersebut kemungkinan karena adanya perbedaan mekanisme hormonal yang mempengaruhi tekanan darah. Selain itu, perbedaan secara signifikan proporsi kejadian hipertensi pada laki-laki dan perempuan mungkin disebabkan oleh kebiasaan merokok yang secara signifikan lebih tinggi pada laki-laki. Hubungan antara rokok dengan peningkatan risiko terjadinya penyakit kardiovaskular telah banyak dibuktikan. Selain lamanya, risiko akibat merokok terbesar tergantung pada jumlah rokok yang dihisap per hari. Seseorang yang merokok lebih dari satu bungkus rokok sehari memiliki risiko dua kali lebih tinggi dari pada yang tidak merokok. Zat kimia beracun, seperti nikotin dan karbon monoksida yang dihisapmelalui rokok, masuk kedalam aliran darah dan merusak lapisan endotel pembuluh darah arteri, mengakibatkan proses aterosklerosis dan hipertensi. Hanya dalam beberapa detik nikotin sudah mencapai otak. Otak bereaksi terhadap nikotin dengan memberi sinyal pada kelenjar adrenal untuk melepas epinefrin (adrenalin). Hormon tersebut akan menyempitkan pembuluh darah dan memaksa jantung untuk bekerja lebih berat karena tekanan yang lebih tinggi. Setelah merokok dua batang saja, tekanan sistolik maupun diastolik akan meningkat 10 mmHg. Tekanan darah akan tetap pada ketinggian ini sampai 30 menit setelah berhenti mengisap rokok. Setelah efek nikotin perlahan-lahan hilang, tekanan darah juga akan menurun dengan perlahan. Pada perokok berat tekanan darah akan berada pada level tinggi sepanjang hari.

Perokok pasif juga berhubungan dengan kerusakan endotel pembuluh darah dan berdampak terhadap peningkatan tekanan darah. Penelitian yang dilakukan oleh Seyedzadeh et al,(2012) menunjukkan bahwa pajanan terhadap asap rokok dapat meningkatkan tekanan darah pada anak dan mempunyai risiko terjadi penyakit kardiovaskuler di kemudian hari.

Penyakit hipertensi berjalan dengan perlahan dan mungkin tidak dirasakan sampai menimbulkan kerusakan organ yang bermakna. Semakin tinggi tekanan darah semakin besar resiko terhadap kerusakan organ tersebut (Price, 2012). Hipertensi yang tidak terkontrol akan menimbulkan berbagai komplikasi, bila mengenai jantung kemungkinan dapat terjadi 
infark miokard, jantung koroner, gagal jantung kongestif, bila mengenai otak terjadi stroke, ensevalopati hipertensif, dan bila mengenai ginjal terjadi gagal ginjal kronis, sedangkan bila mengenai mata akan terjadi retinopati hipertensif. Dari berbagai komplikasi yang mungkin timbul merupakan penyakit yang sangat serius dan berdampak terhadap psikologis penderita karena kualitas hidupnya rendah terutama pada kasus stroke, gagal ginjal, dan gagal jantung. Tekanan darah yang tinggi umumnya meningkatkan resiko terjadinya komplikasi tersebut. Hipertensi yang tidak diobati akan mempengaruhi semua sistem organ dan akhirnya memperpendek harapan hidup sebesar 10-20 tahun (Cardiology, 2014).

Mortalitas pada pasien hipertensi lebih cepat apabila penyakitnya tidak terkontrol dan telah menimbulkan komplikasi ke beberapa organ vital. Sebab kematian yang sering terjadi adalah penyakit jantung dengan atau tanpa disertai stroke dan gagal ginjal (Hoeymans, 1999). Oleh karena itu pengobatan hipertensi memang menjadi suatu hal yang penting, tetapi tidak lengkap jika tanpa dilakukan tindakan pencegahan untuk menurunkan faktor resiko penyakit kardiovaskuler akibat hipertensi.

\section{PENUTUP}

Hasil penelitian menunjukkan bahwa dari 147 responden sepertiganya sudah mengalami hipertensi dengan sebaran hipertensi stage 2 sebanyak 9 orang $(6,1 \%)$, hipertensi stage 1 sebanyak 18 orang $(12,2 \%)$, dan pre-hipertensi sebanyak 22 orang $(15,0 \%)$, dan sebanyak 98 orang $(66,7 \%)$ yang mempunyai tekanan darah normal. Hipertensi pada remaja perlu diwaspadai sehingga penting untuk rutin mengukur tekanan darah pada anak remaja. Berbagai faktor risiko hipertensi perlu diperhatikan pada anak remaja.

Saran, perlu dilakukan upaya pencegahan sejak dini yang berkaitan dengan pola makan dan gaya hidup pada remaja, meliputi: perubahan pola makan, pembatasan penggunaan garam hingga 4-6 gr per hari, makanan yang mengandung soda kue, bumbu penyedap dan pengawet makanan, mengurangi makanan yang mengandung kolesterol tinggi (jeroan, kuning telur, cumi-cumi, kerang, kepiting, coklat, mentega, dan margarin), menghentikan kebiasaan merokok, minum alcohol, olah raga teratur dan menghindari stress.

\section{DAFTAR PUSTAKA}

Angesti, AN., Triyanti, Sartika, RAD. 2018. Riwayat Hipertensi Keluarga Sebagai Faktor Dominan Hipertensi Pada Remaja Kelas XI SMA Sejahtera 1 Depok Tahun 2017. Buletin Penelitian Kesehatan. 46(1): $1-10$.

Arianto. 2013. Komunikasi Kesehatan. Jurnal Ilmu Komunikasi. 3(2): 1-13.

Arum, YTG. 2019. Hipertensi pada Penduduk Usia Produktif (15-64 Tahun). HIGEIA. 3(3): 34556.

Bloch, M. J. 2016. Worldwide Prevalence of Hypertension Exceeds 1.3 Billion. Journal of The American Society of Hypertension, 10(10):753- 754.

Butch, Nirav et al. 2011. Prevalence of hipertension in chool going childrenof surat city, western india. Journal of cardiovascular disease research Oct-Dec; 2(4): 228-232.

Dharnidharka EA. 2015. Hypertension in The Teenager. Natl Institutes Heal. 61(1):131- 51.

Fitrianingsih, Siswanto, Y. Tarmali, A. 2016. Beberapa Faktor Yang Berhubungan Dengan Kejadian Hipertensi Pada Remaja Di SMAN 1 Ungaran Kabupaten Semarang. Jurnal Gizi dan Kesehatan. 8(17): 33-39.

Grad, I., Migas, AM., Pstrusińska, KK. 2015. Factors Associated With Knowledge Of Hypertension Among Adolescents: Implications For Preventive Education Programs In Primary Care. BMC Public Health. 15(463): 2-8.

Kemenkes R.I. 2013. Riset Kesehatan Dasar. Jakarta: Kementerian Kesehatan Republik Indonesia.

Kemenkes R.I. 2018, Laporan Nasional Riskesdas 2018, Jakarta: Kementerian Kesehatan Republik Indonesia.

Kini S., Kamath V.G., Kulkarni M.M., Kamath A., Shivalli, S. 2016. Pre-Hypertension among Young Adults (20-30 Years) in Coastal Villages of Udupi District in Southern India: An Alarming Scenario. PLoS ONE, 11(4).

Kurnianingtyas, BF., Suyatno, Kartasurya, IM., 2017. Faktor Risiko Kejadian Hipertensi Pada 
Siswa SMA Di Kota Semarang Tahun 2016. Jurnal Kesehatan Masyarakat (e-Journal). 5(2): 70-77.

Notoatmodjo,Soekijo.2012. Promosi Kesehatan Dan Perilaku Kesehatan, Jakarta: Rineka Cipta.

Nuraini B. 2015. Risk Factors of hypertension. $J$ Major. 4(5):10-9.

Park, J.B., Kario, K., dan Wang, J.G. 2015. Systolic Hypertension: an Increasing Clinical Challenge in Asi. Hypertension Research. 38(4) : 227-236.

Price SA, Wilson LM. 2012. Patofisiologi konsep klinis proses-proses penyakit, edisi ke-6. Jakarta: EGC.

Sangamesh, V.S. 2016. Prevalence of Hypertension in Urban School Going Adolescents of Bangalore, India. International Journal of Contemporary Pediatrics, 3(2): 416 - 423 doi: 10.18203/23493291.ijcp20160488.

Santoso, D. 2013. Prevalence of Hypertension in School and College Students. Jurnal Kesehatan Masyarakat Nasional. 7(11): 509-513.
Seyedzadeh A, Hashemi F, Soleimani A. Relationship between blood pressure and passive smoking in elementarry school children. Iran J Pediatr. 2012;22:351-6

Shapo L, Pomerleau J, McKee M. Epidemiology of Hypertension and Associated Cardiovascular Risk Factors in a Country in Transition. Albania: Journal Epidemiology Community Health 2003;57:734-739

Sukarmin, 2013. Penurunan TeKanan Darah Pasien Hipertensi Melalui Brisk Wilking Eksercise. Jurnal Keperawatan Indonesia Vol. 16 Maret 2013.

WHO. 2018. Global Health Estimates 2016: Deaths by Cause, Age, Sex, by Country and by Region, 20002016. Geneva: World Health Organization.

Yusrizal, M., Indarto, D., Akhyar,M., 2016. Risk of Hypertension in adolescents with over nutritional status in Pangkalpinang, Indonesia. Journal of Epidemiology and Public Health. 1(1): 30-39. 